A Revista Em Construção: arquivos de epistemologia histórica e estudos de ciência publica em seu nono número o dossiê temático: "Diásporas, Dissidências e Devastações", com artigos, ensaios e entrevistas, além de um artigo na sessão varia sobre a noção de progresso científico em Thomas Kuhn. Tais trabalhos conversam, em certa medida, com preocupações atuais acerca da produção de conhecimento no âmbito acadêmico e científico. O cenário de crise ambiental, sanitária, econômica, política, ética e, por que também não dizer, estética nos motivou a aceitar a publicação deste dossiê como uma contribuição à importância da reflexão constante sobre os critérios que atuam na produção de conhecimento.

O que está em jogo nos trabalhos aqui publicados é tanto uma reflexão sobre a relação entre ciência e sociedade quanto às condições de possibilidade da construção de conhecimento. Uma tal abordagem, tão presente nas pesquisas e debates contemporâneos, requer não apenas um esforço de ampliação de agentes que compõem o fazer científico, isto é, quem produz conhecimento, mas também uma abertura hermenêutica e metodológica, para que outras ferramentas teóricas e problemas componham o quê e o como do conhecimento.

Em tempos de crise e desconfiança sobre a produção de conhecimento científico, a Em Construção espera, com o presente número, reafirmar o compromisso e a importância de critérios que permitam a expressão da diversidade constitutiva da comunidade científica e de seu modo de produção, assim como a garantia de sua confiabilidade. O deslocamento proposto aqui por muitas vozes tem a coragem de questionar a naturalização ou visão única da produção de conhecimento como projeto Moderno e Ocidental. Essa visão, que nos levou à fatalidade de um mundo apartado pelo sistema natureza-cultura, alienou da história do conhecimento agentes que agora se afirmam em suas localizações, ao mesmo tempo em que afirmam também o caráter localizado da, por assim dizer, tradição. Ou nas palavras de Ailton Krenak, em O amanhã não está à venda: "Fomos, durante muito tempo, embalados com a história de que somos a humanidade e nos alienamos desse organismo de que somos parte, a Terra(...) Eu não percebo que exista algo que não seja natureza. Tudo é natureza. O cosmos é natureza. Tudo em que eu consigo pensar é natureza” (KRENAK, 2020, p.5).

Em consonância com os objetivos que buscamos seguir nos cinco anos de publicação deste periódico, acreditamos que o presente número possa contribuir para um esperançar em nossas atividades de pesquisa, ensino e extensão apesar de, mas também e, sobretudo, com um mundo em devastações.

\title{
Antonio Augusto Passos Videira
}

Maria Helena Soares

Carlos Puig

Editores da Revista Em Construção 